\title{
Post-ride inflammatory markers in endurance horses
}

\author{
Marcadores inflamatórios em cavalos após enduro
}

\section{Renata Farinelli de Siqueira ${ }^{\mathrm{I}^{*}}$ Wilson Roberto Fernandes ${ }^{\mathrm{I}}$}

\section{ABSTRACT}

The acute phase reaction occurs in response to diseases, surgical trauma and can happen after strenuous exercise, like long distance events. This study aimed to evaluate the Serum Amyloid A (SAA), pro-inflammatory interleukins (IL-1 $\beta$ and TNF $\alpha$ ) and creatine phosphokinase (CK) after free speed races like physical stress markers in endurance horses. Blood of 21 trained horses that competed in tests of 80,120 and $160 \mathrm{~km}$, was taken before and after race. There was a significant increase in CK and SAA after the race in all horses, as well as the anti-inflammatory interleukin IL-10. But when results were compared between the groups, only the SAA was different, being higher in $160 \mathrm{~km}$ horses. There was no change in pro-inflammatory interleukins $I L-1 \beta$ and $T N F \alpha$ before and after the event; however, the TNF $\alpha$ was higher in $160 \mathrm{~km}$ horses after the race. Based on data obtained in this study it was concluded that stress is more dependent on the distance than speed imposed and that $S A A$ is a good marker of physical effort, since it is accompanied by other markers well established as CK. Interleukins are not a good markers since they did not change significantly.

Key words: inflammation, endurance, horses.

\section{RESUMO}

A reação de fase aguda da inflamação ocorre como resposta a doenças, traumas cirúrgicos e pode acontecer após exercicio físico extenuante, como provas de longa distância. $O$ presente estudo teve por objetivo avaliar o Amiloide A Sérico (SAA), interleucinas pró-inflamatórias e a enzima creatinafosfoquinase (CK) após provas de velocidade livre como marcadores de esforço fisico em cavalos de enduro. Utilizou-se sangue de 21 cavalos devidamente treinados, que competiram em provas de 80, 120 e $160 \mathrm{~km}$, colhido antes e depois da prova. Houve aumento significativo em CK e SAA após a prova em todos os cavalos, assim como da interleucina anti-inflamatória IL-10. Porém, quando os resultados foram comparados entre os grupos, somente a SAA apresentou diferença, sendo maior nos cavalos de $160 \mathrm{~km}$. Não foi observada alteração nas interleucinas pró-inflamatórias $I L-1 \beta$ e TNF $\alpha$ antes e depois da prova, todavia, o TNF $\alpha$ foi maior nos cavalos de $160 \mathrm{~km}$ após a prova. Baseado nos dados obtidos neste estudo, conclui-se que o esforço é dependente da distância percorrida e não da velocidade imposta e que a SAA é um bom marcador de esforço fisico, desde que acompanhada de outros marcadores já consagrados, como a CK. As interleucinas não se apresentaram bons marcadores, já que não sofreram alterações significativas.

Palavras-chave: inflamação, enduro, cavalos.

\section{INTRODUCTION}

Exercise can be one of the most stressful stimuli that animal can experience throughout his life. During high-performance exercise occur reversible homeostatic changes in horses' metabolism. Long duration exercises, such as endurance races, represent important stimulus to those variables, due to strenuous environmental factors, and central and peripheral fatigue (CYWINSKA et al., 2012).

Primary immune body reaction to stress is the innate immune response, being not specific. Nonspecific components of the immune system, acute phase proteins (APPs) inhibit the continuity of tissue damage, isolating and destroying the pathogenic agent and activating the process of tissue repair necessary for returning to normality (MURATA et al., 2004). These proteins are induced by pro-inflammatory cytokines IL-1, TNF $\alpha$ and IL-6 that activate receptors

\footnotetext{
'Departamento de Clínica Médica, Faculdade de Medicina Veterinária e Zootecnia (FMVZ), Universidade de São Paulo (USP), Av. Dr. Orlando Marques da Paiva, 87, Bloco 15, Cidade Universitária, 05508-270, São Paulo, SP, Brasil.. E-mail: refarinelli@yahoo.com.br. ${ }^{*}$ Corresponding author.
} 
on various target cells and promote metabolic and hormonal changes that trigger local and systemic effects. Haptoglobin, C-reactive protein and Serum Amyloid A are the more reactive acute phase proteins in some animals and humans (PETERSEN et al., 2004; GRUYS et al., 2005).

There are controversial on the capacity of exercise to promote an acute phase reaction. FALLON et al. (2001) studied ultramarathon runners and showed the existence of this reaction in these athletes, of similar magnitude to those described in postoperative patients or those with serious illnesses. However, more recent studies with horses showed the presence of acute phase reaction after exertion competition in polo (GONDIN et al., 2013) and endurance (CYWINSKA et al., 2012). The results suggest that such proteins can be, like the biomarkers already established, an important indicator of metabolic activity in muscle fiber.

Monitoring the concentration of such variables associated with the inflammation and immune stress can contributing to defining the level of effort performed by the horses in different equestrian disciplines. Furthermore, it may represent a new tool performance study in athletic horses. This study aimed to evaluate the Serum Amyloid A and pro-inflammatory interleukins after endurance race as physical stress markers in endurance horses.

\section{MATERIALS AND METHODS}

Twenty one Arabian horses trained for endurance rides and properly graduated to the free running speed races $(5$ to $160 \mathrm{~km}, 120 \mathrm{~km}$ and 8 in 8 in $80 \mathrm{~km}$ ) were tested. They came from private owners in the state of São Paulo, Brazil. Race was held in July in Pirassununga, São Paulo. All animals were fed with roughage and commercial concentrate up to 5 hours prior to start and were supplemented with electrolyte solutions during the course. They also had a free access to water and in the mandatory stops, received grass hay.

Blood was collected from the jugular vein in vacuum vials without anticoagulant only horses that completed the race in the moments before start (M0) and immediately after the approval of last veterinary inspection (M1), just off the confined area of the vet check.

SAA was analyzed by enzyme-linked immunosorbent ELISA assay kit using multispecies Tridelta (Phase Assay Serum Amyloid A). Interleukins IL-10 and TNF $\alpha$ were determined by the equine specific brand duo sets R \& D Systems (DY1605 and DY1814, respectively). IL-1 $\beta$ (interleukin 1 beta) was determined using the Bethyl kit for horses mark (Horse IL-1 $\beta$ ELISA kit E77-805). All plates were performed in triplicate, according to the manufacturer's instructions and read on reader EL 808 (Bio-Tek Instruments, United States).

The activity of the enzyme creatine phosphokinase (CK) was evaluated by the kinetic method in biochemical analyzer (Daytona ${ }^{\circledR}$, Randox, United Kingdom) using specific kit Randox.

Analysis results were performed by using the computerized statistical program GraphPad InStat (version 3.0). They were evaluated for normality by Kolmorov-Smirnov test following analysis of variance (ANOVA) and comparison of means (Tukey test) with 5\% significance level.

\section{RESULTS AND DISCUSSION}

The good physical conditioning is crucial for success in free speed endurance races, especially nowadays, that speeds are higher and higher. There was statistical difference in average speed between groups $(\mathrm{P}=0.001)$. Horses that compete in the $80 \mathrm{~km}$ race obtained average speed $(20.46 \pm 1.7)$ higher than horses that competed in $120 \mathrm{~km}(18.85 \pm 1.4)$ and $160 \mathrm{~km}(17.82 \pm 1.3)$ respectively as observed in figure 1. All horses used in this study, finished the race in good health and were approved in the final veterinary inspection. The mean values and standard deviation of the SAA, IL-1 $\beta$, TNF $\alpha$ and CK horses that competed in different distances before and after the race are in table 1.

There was a significant increase in CK enzyme activity and this finding has been observed in response to exercise as a result of changes in the muscle fiber membrane which causes transient increase in permeability (HINCHCLIFF et al., 2004). According to MARCELLA (2008), this reaction is temporary; however, the CK activity can easily increase up to a hundred times due to the exercise without being associated with any disease. This is routinely seen in endurance horses completing the tests successfully. In the present study exercise was intense enough to produce changes of the enzyme described above, with significant increase in post-test on all animals and this increase was proportional to the distance traveled; i.e,. it was higher in horses that had done $160 \mathrm{~km}$, followed by 120 and finally by $80 \mathrm{~km}$. MARLIN et al. (2002) and CYWINSKA et al. (2012) studied horses long distance and obtained similar results. However, when results between the groups were compared there was no statistical difference $(\mathrm{P}=0.087)$, which 


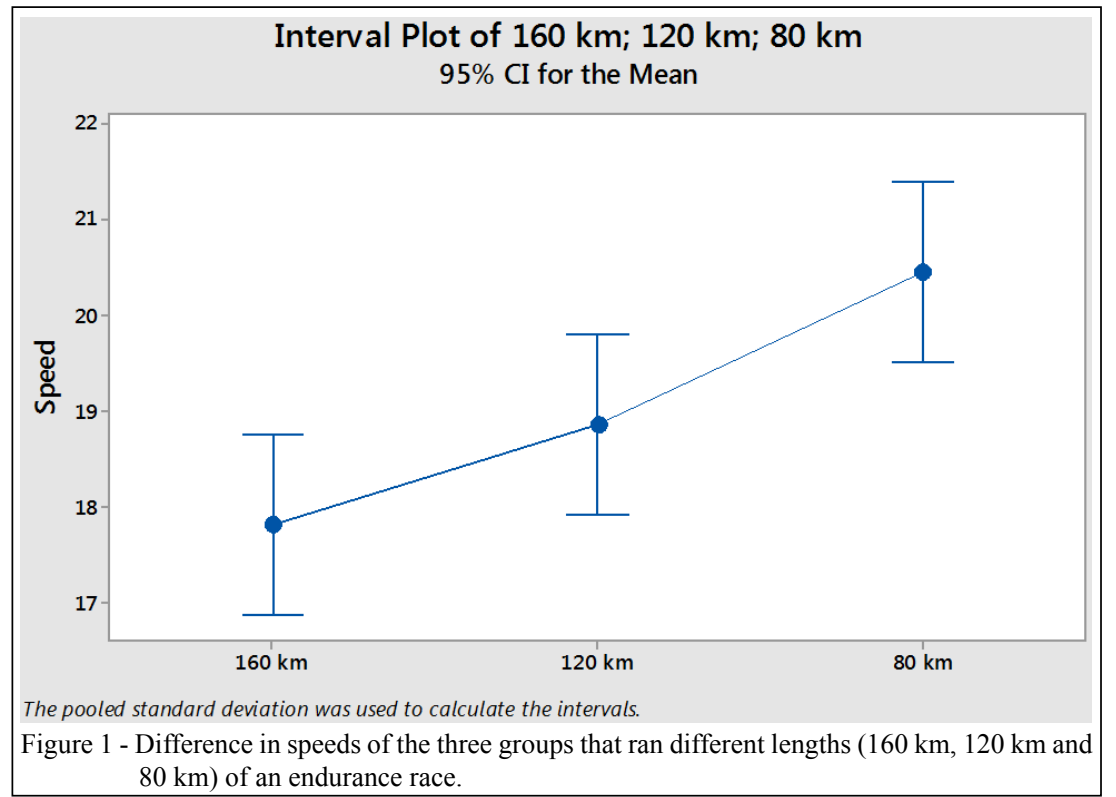

suggested that the increase of this enzyme may be physiological, which does not necessarily indicate a degree of fatigue.

The intense exercise produces an inflammatory reaction (acute phase reaction) with a change of acute phase proteins by both glycogen depletion, as e microlesions musculature, reported in sled dogs (WAKSHLAG et al., 2010); hunting dogs (CASELLA et al., 2013) and horses (JACOBSEN \& ANDERSEN, 2007; CYWINSKA et al., 2010; CYWINSKA et al., 2013). This acute phase reaction is induced by pro-inflammatory cytokines IL-1, TNF $\alpha$ and IL-6, activate receptors on various target cells and promote metabolic and hormonal changes, leading to a systemic effect, including the acute production phase of protein in the liver (PETERSEN et al., 2004;. GRUYS et al., 2005).

Serum Amyloid A (SAA), a multigene family of HDL (high density lipoprotein) apolipoproteins (apo), is reported in mammals and birds. They are the major acute-phase reactants whose plasma levels are elevated several hundred to 1000 fold as part of a response to various injuries including trauma or infection. While the exactly function of the apoSAAs is not known, they must have considerable physiological significance apart from the role as

Table 1 - Values (mean \pm standard deviation) of SAA, IL-1 $\beta$, TNF $\alpha$ and CK of horses that have competed at different distances in an endurance race before (T0) and after the competition (T1).

\begin{tabular}{|c|c|c|c|c|c|}
\hline & SAA (ng mL $L^{-1}$ ) & IL-1 $\beta\left(\mathrm{ng} \mathrm{mL}^{-1}\right)$ & $\mathrm{TNF} \alpha\left(\mathrm{ng} \mathrm{mL}^{-1}\right)$ & IL-10 (ng mL $\left.\mathrm{mL}^{-1}\right)$ & $\mathrm{CK}\left(\mathrm{U} \mathrm{L}^{-1}\right)$ \\
\hline \\
\hline T0 & $883( \pm 1.3)^{\mathrm{A}}$ & $487( \pm 0.2)^{\mathrm{A}}$ & $1607( \pm 0.9)^{\mathrm{A}}$ & $4433( \pm 2.4)^{\mathrm{A}}$ & $120,9( \pm 3.1)^{\mathrm{A}}$ \\
\hline $\mathrm{T} 1$ & $14975( \pm 1.09)^{\mathrm{B}^{*}}$ & $547( \pm 0.3)^{\mathrm{A}}$ & $1931( \pm 1.0)^{\mathrm{A}}$ & $12069( \pm 3.2)^{\text {В }}$ & $753,0( \pm 4.1)^{\text {В }}$ \\
\hline T0 & $703( \pm 1.4)^{\mathrm{A}}$ & $408,7( \pm 0.2)^{\mathrm{A}}$ & $\begin{array}{l}-120 \mathrm{~km}------- \\
1617( \pm 0.7)^{\mathrm{A}}\end{array}$ & $5939( \pm 3.8)^{\mathrm{A}}$ & $122,9( \pm 4.8)^{\mathrm{A}}$ \\
\hline $\mathrm{T} 1$ & $5117( \pm 3.1)^{\mathrm{B}^{*}}$ & $474( \pm 0.2)^{\mathrm{A}}$ & $1765( \pm 0.9)^{\mathrm{A}}$ & $12872( \pm 3.1)^{\text {В }}$ & $844,0( \pm 3.6)^{\mathrm{B}}$ \\
\hline T0 & $341( \pm 2.7)^{\mathrm{A}}$ & $616( \pm 0.2)^{\mathrm{A}}$ & $2815( \pm 0.4)^{\mathrm{A}}$ & $7957( \pm 3.2)^{\mathrm{A}}$ & $101,6( \pm 2.1)^{\mathrm{A}}$ \\
\hline $\mathrm{T} 1$ & $7268( \pm 3.1)^{\mathrm{B}^{*}}$ & $727( \pm 0.2)^{\mathrm{A}}$ & $3135( \pm 0.5)^{\mathrm{A}^{*}}$ & $22947( \pm 2.1)^{\mathrm{B}}$ & $2055,0( \pm 1.2)^{\mathrm{B}}$ \\
\hline
\end{tabular}

Different letters in the same column indicate difference between the sample times $(\mathrm{P}<0.05) .{ }^{*}$ In the same column indicates statistical difference $(\mathrm{P}<0.05)$ of the same variable between groups $(80,120$ and $160 \mathrm{~km})$.

SAA: Serum Amyloid A; IL-1 $\beta$ : interleukine 1 beta; TNF $\alpha$ : tumor necrosis factor alpha; IL-10: interleukine 10; CK: creatine phosphokinase.

Ciência Rural, v.46, n.7, jul, 2016. 
the precursor of amyloid A protein fibrils (MEEK et al., 1994). SAA may play an important role in recruiting $\mathrm{T}$ lymphocytes, as well as neutrophils and monocytes into inflammatory lesions and cause the release of TNF $\alpha$ from lymphocytes and of IL-1 $\beta$ from monocytic cells (FURNALETO \& CAMPA, 2000). Because the apoSAAs are acute phase reactants, the liver has been considered to be the primary site of expression, where they are induced by inflammatory cytokines IL-1 and IL-6 and TNF $\alpha$ (MEEK et al., 1994).

Serum Amyloid A is recognized as the most acute phase protein in horses and may increase by 10 to 100 times in inflammation, reaching values above 20,000ng $\mathrm{mL}^{-1}$ (HINCHCLIFF et al., 2004; HOBO et al., 2007). As normal levels for SAA are not yet well established, CYWINSKA et al. (2010) worked with healthy endurance horses and concluded that before the race, all horses presented above $1000 \mathrm{ng} \mathrm{mL}^{-1}$ levels were eliminated. In the present study it was used the same kit and got the same result. Because only the horses were considered approved in the final veterinary inspection, all the horses showed levels below $1000 \mathrm{ng} \mathrm{mL}^{-1}$, but we have no data of animals eliminated.

In the present study, when the results were analyzed within each group there was a increase in post-race SAA concentrations in all horses and it was proportionally greater in $160 \mathrm{~km}$ horses followed by $120 \mathrm{~km}$ and than $80 \mathrm{~km}$. CYWINSKA et al. (2012) evaluated SAA in endurance horses of regularity and free speed and also reported' large increase in post-test of animals that ran longer distances, to more than 10 times, which corroborates this study. When the results were analyzed between different groups of SAA also increase that followed this same logic $(160 \mathrm{~km}>120 \mathrm{~km}>80 \mathrm{~km} ; \mathrm{P}=0.040)$ increasing based on the distance covered and not according to the highest speed, since the faster group was the $80 \mathrm{~km}$. Perhaps the most important function of SAA is right in the cellular repair since levels were higher in horses that raced longest distances.

The results of the TNF $\alpha$ and IL-1 $\beta$ dosages are controversial, both in horses and humans (MOLDOVEANU et al., 2000). Interleukin-1 is a pro-inflammatory cytokine produced by macrophages, monocytes and dendritic cells. Data on exercise-induced alterations in IL-1 $\beta$ are mixed with some non horse papers documenting that IL- $1 \beta$ is among the first cytokine to increase in response to exercise and some reporting no change due to exertion (LIBURT et al., 2010). Tumor necrosis factor alpha is a pro-inflammatory cytokine that has been used as a general marker of acute inflammation (PEDERSEN \& HOFFMANGOETZ, 2000; SUZUKI et al., 2002) and plays a role in response to muscle damage (KIMURA et al., 2001), muscle proteolysis (NAWABI et al., 1990) and impaired skeletal muscle glucose uptake (STEENSBERG et al., 2002).

There was a trend of increase in all horses after the race, although it was not significant. These results agree with SUZUKI et al. (1999; 2000) and COLAHAN et al. (2002), which reported no significant increase after long-term exercise. PEDERSEN \& HOFFMANGOETZ (2000) and DONOVAN et al. (2007) also reported increased $\mathrm{TNF} \alpha$ after exhaustive exercise. There seems to be an increase of these interleukins like a cascade. Soon after the given stimulus occurrence an increase of serum TNF $\alpha$ and IL- $1 \beta$ stimulated the liver to produce acute phase proteins. Probably for this reason we could not note significant increase of these interleukins soon after the race; however, at the same moment it was observed marked increase of SAA. But when data were compared between groups there was a difference in $\mathrm{TNF} \alpha$ before $(\mathrm{P}=0,01)$ and after $(\mathrm{P}=0,02)$ the race, and $160 \mathrm{~km}$ horses showed higher concentrations of this cytokine even at rest. This result added to SAA support the hypothesis that inflammation is proportional to the distance and not to the imposed speed.

There was also a significant increase of IL-10 in all horses after the test. IL-10 has a broad range of anti-inflammatory properties as inactivation of macrophages and dendritic cell maturation, thus inhibiting the secretion of proinflammatory cytokines (TNF $\alpha$ ), and expression of MHC class II. It also inhibits the production of IL-12 by macrophages and dendritic cells, which make this interleukin having a direct suppressive effect on the Th1 lymphocyte response. So as IL- $1 \alpha$, IL- $1 \beta$ and TNF $\alpha$ and IL- 8 , cytokines, and chemokines play important roles in the activation of granulocytes, NK cells and T and B lymphocytes (O'GARRA \& VIEIRA, 2007). The increase in IL-10 concentration in all horses after this study indicated that interleukin may have similar effect on the horse that has in humans, modulating the inflammatory response (O'GARRA \& VIEIRA, 2007), which have not been significantly increased concentrations IL- $1 \beta$ and TNF $\alpha$ after the race. However, when we compare the results between the groups, there was no statistical difference before $(\mathrm{P}=0,50)$ and after $(\mathrm{P}=0,61)$ the race. 


\section{CONCLUSION}

According to the data obtained in this study it was concluded that inflammation resulting from the endurance exercise is more closely related to the effort produced by greatest distances than the highest speeds.

The SAA is recognized as the most sensitive APP on horses but it's exactly function in skeletal muscle is still unknown as well as their normal values. Based on our data, we believed that it may be a good indicator of physical effort as long as it is associated with other well established markers such as $\mathrm{CK}$, for example. Pro-inflammatory interleukins cannot be used for this purpose, since it did not change or suffer action of other anti-inflammatory interleukins.

\section{BIOETHICS AND BIOSSECURITY COMMITTE APPROVAL}

This study was approved by the Ethics Committee on Animal Use of the Faculdade de Medicina Veterinária e Zootecnia (FMVZ), Universidade de São Paulo (USP) in São Paulo, Brazil with the protocol number 2606/2012.

\section{REFERENCES}

COLAHAN, P.T. et al. Does training affect mRNA transcription for cytokine production in circulating leukocytes? Equine Veterinary Journal, v.34, p.154-158, 2002. Available from: $<$ http://onlinelibrary.wiley.com/doi/10.1111/j.2042-3306.2002. tb05409.x/epdf>. Accessed: Nov. 02, 2014. doi: 10.1111/ j.2042-3306.2002.tb05409.x.

CYWINSKA, A. et al. Serum AmyloidA level as a potential indicator of the status of endurance horses. Equine Veterinary Journal, v.42 (Suppl.38), p.23-27, 2010. Available from: <http://onlinelibrary. wiley.com/doi/10.1111/j.2042-3306.2010.00280.x/epdf > . Accessed: Jul. 10, 2012. doi: 10.1111/j.2042-3306.2010.00280.x.

CYWINSKA, A. et al. Acute phase protein concentration after limited distance and long distance endurance rides in horses. Research in Veterinary Sciences, v.93, n.3, p.14021406, 2012. Available from: <https://www.researchgate. net/publication/221888572_Acute_phase_protein concentrations after limited distance and long distance endurance_rides_in_horses $>$. Accessed: Aug. 03, 2013. doi: 10.1016/j.rvsc. 2012.02 .008 .

CYWINSKA, A. et al. Serum Amyloid A (SAA) concentration after training sessions in Arabian race and endurance horses. BMC Veterinary Research, v.9, n.91, p.1-7, 2013. Available from: $<$ http://www.biomedcentral.com/1746-6148/9/91>. Accessed: Dec. 18, 2013. doi: 10.1186/1746-6148-9-91.

DONOVAN, D.C. et al. Exercise-induced alterations in proinflammatory cytokines and prostaglandin F2 $\alpha$ in horses. Veterinary Immunology and Immunopathology, v.118, p.263-269, 2007. Available from: <http:/www.sciencedirect.com/science/article/pii/ S0165242707001791>. Accessed: Feb. 12, 2012. doi: 10.1016/j. vetimm.2007.05.015
FALLON, K.E. The acute phase response and exercise: the ultramarathon as prototype exercise. Clinical Journal of Sports Medicine, v.11, p.38-43, 2001. Available from: <http://journals. lww.com/cjsportsmed/pages/articleviewer.aspx? year=2001\&issue $=01000 \&$ article=00007\&type $=$ abstract $>$. Accessed: Feb. 12, 2012.

FURNALETO, C.J.; CAMPA, A. Anovel function of serum amyloid a: a potent stimulus for the release of tumor necrosis factor-a, interleukin- $1 \mathrm{~b}$, and interleukin- 8 by human blood neutrophil. Biochemical and Biophysical Research Comunications, v.268, p.405-408, 2000. Available from: $<$ http://www.sciencedirect.com/ science/article/pii/S0006291X00921430>. Accessed: Apr. 27, 2012. doi: $10.1006 /$ bbrc.2000.2143.

GONDIN, M.R. et al. Acute phase response to different positions of high-goal (Elite) Polo Ponies. Journal of Equine Veterinary Science, v.33, n.11, p.956-961, 2013. Available from: <http:// www.j-evs.com/article/S0737-0806(13)00089-0/fulltext $>$. Accessed: Dec. 10, 2013. doi: 10.1016/j.jevs.2013.02.005.

GRUYS, E. et al. Acute phase reaction and acute phase proteins. Journal of Zhejiang University Science, v.6, n.11, p.1045-1056, 2005. Available from: <http://www.ncbi.nlm.nih. gov/pmc/articles/PMC1390650/>. Accessed: Apr. 27, 2012. doi: $10.1631 /$ jzus.2005.B1045.

HINCHCLIFF, H. et al. Equine sports medicine and surgery. Edinburgh, New York: Saunders, 2004. p. 1245.

HOBO, S. et al. Evaluation of serum amyloid A (SAA) and surfactant protein D in sera for identification of the clinical condition of horses with bacterial pneumonia. Journal of Veterinary Medicine Science, v.69, p.827-830, 2007. Available from: <https://www.jstage.jst.go.jp/article/jvms/69/8/69_8_827/_ article>. Accessed: Apr. 27, 2012. doi: 10.1292/jvms.69.827.

JACOBSEN, S.; ANDERSEN, P.H. The acute phase protein serum amyloid A (SAA) as a marker of inflammation in horses. Equine Veterinary Education, v.19, p.38-46, 2007. Available from: $<$ http://onlinelibrary.wiley.com/doi/10.1111/j.2042-3292.2007. tb00550.x/abstract>. Accessed: Apr. 27, 2012. doi: 10.1111/ j.2042-3292.2007.tb00550.x.

MARCELLA, K. Blood analysis and performance assessment. American Endurance Ride Conference, 2008. Available from: $<$ http://www.aerc.org/ENJuly08Ed.asp>. Accessed: Apr. 27, 2012.

MARLIN, D.; NANKERVIS, K. Equine exercise physiology. Oxford: Blackwell Science, 2002. p. 296.

MEEK, R.L. et al. Expression of apolipoprotein serum amyloid A mRNA in human atherosclerotic lesions and cultured vascular cells: Implications for serum amyloid A function. Proceedings of the National Academy of Sciences, v.91, p.3186-3190, 1994.

MOLDOVEANU, A.I. et al. Exercise elevates plasma levels but not gene expression of IL-1b, IL-6, and TNF- $\alpha$ in blood mononuclear cells. Journal of Applied Physiology, v.89, n.4, p.1400-1509, 2000. Available from: <http://jap.physiology.org/ content/89/4/1499>. Accessed: Apr. 27, 2012.

O'GARRA, A.; VIEIRA, P. Th1 cells control themselves by producing interlukin-10. Nature Reviews, Immunology, v.7, n.6, p.425-428, 2007. Available from: <http://www.nature.com/ nri/journal/v7/n6/full/nri2097.html>. Accessed: May 28, 2013. doi:10.1038/nri2097. 
PEDERSEN, B.K.; HOFFMAN-GOETZ, L. Exercise and the immune system: regulation, integration, and adaptation. Physiological Reviews, v.80, n.3, p.1055-1081, 2000. Available from: <http://physrev. physiology.org/content/80/3/1055>. Accessed: Aug. 11, 2010.

PETERSEN, H.H. et al. Application of acute phase protein measurements in veterinary clinical chemistry. Veterinary Research, v.35, n.2, p.163-187, 2004. Available from: $<$ https://hal.archivesouvertes.fr/hal-00902823>. Accessed: Jun. 26, 2013. doi: 10.1051/ vetres:2004002.

SUZUKI, K. et al. Endurance exercise causes interaction among stress hormones, cytokines, neutrophil dynamics, and muscle damage. Journal of Applied Physiology, v.87, n.4, p.1360-1367, 1999. Available from: <http://jap.physiology.org/content/87/4/1360.long> Accessed: Jul. 14, 2011.
SUZUKI, K. et al. Circulating cytokines and hormones with immunosuppressive but neutrophil-priming potentials rise after endurance exercise in humans. European Journal of Applied Physiology, v.81, n.4, p.281-287, 2000. Available from: <http://www.ncbi.nlm.nih.gov/pubmed/10664086>. Accessed: Jul. 14, 2011

WAKSHLAG, J.J. et al. Evaluation of exercise - induced changes in concentration of C-reactive protein and serum biochemical values in sled dogs competing a long distance endurance race. American Journal of Veterinary Research, v.71, n.10, p.1207-1213, 2010. Available from: <http:// avmajournals.avma.org/doi/abs/10.2460/ajvr.71.10.1207?url ver $=$ Z39.88-2003\&rfr_id=ori\%3Arid\%3Acrossref.org\&rfr_ dat $=$ cr_pub\%3Dpubmed\&>. doi: $10.2460 /$ ajvr.71.10.1207. 